\title{
The Influence of Collaborative Model between the Role of Husbands and Healthcare Workers on Mother's Behavior in Giving Exclusive Breastfeeding
}

\author{
Stang Stang ${ }^{1 *}$, Tahir Abdullah ${ }^{1}$, Sumarni Marwang ${ }^{2}$ \\ ${ }^{1}$ Department of Biostatistics, Faculty of Public Health, Universitas Hasanuddin, Makassar, Indonesia; ${ }^{2}$ Midwifery Study Program, \\ Faculty of Midwifery and Nursing, Megarezky University, Makassar, Indonesia
}

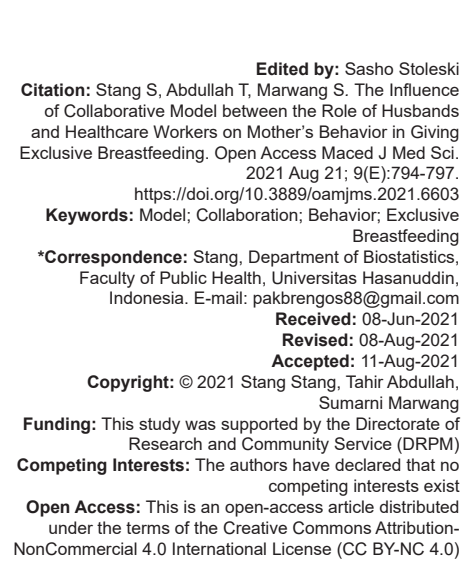

\section{Introduction}

The basic capital for the formation of a quality human being starts when the baby is in the womb, accompanied by the provision of breast milk (ASI) from an early age [1], [2], [3]. Breast milk helps optimal growth and development as well as gives protection against disease. The benefits of breastfeeding will be more optimal if breastfeeding is done exclusively without other additional food, for the first 6 months of life. The process of exclusive breastfeeding can be started immediately after the baby is born, this process in the world of health is called Early Initiation of Breastfeeding (IMD) [4], [5].

Every year, 1-1.5 million babies in the world are died because they are not exclusively breastfed. Furthermore, around 30,000 deaths of toddlers in Indonesia can be prevented by exclusive breastfeeding. According to the results of a survey of data and information on the 2018 Indonesian Health Profile, the percentage of newborns receiving IMD reached $71.34 \%$, even so, the number is still far from the target of $90 \%$. While the percentage of babies who were exclusively breastfed is $65.16 \%$, this number is still low when referring to the target achievement which must exceed $80 \%$ [6].

In Barru District, in 2018, the number of children receiving breastfeeding was $58.9 \%$. This number is far from the target set at $80 \%$. The achievement rate for exclusive breastfeeding at each health center in Barru District in 2018 was varied, the lowest was at Mangkoso puskesmas at $12.5 \%$ and followed by Padongko puskesmas at $35.8 \%$ [7].

The success of mothers in carrying out IMD and exclusive breastfeeding is strongly influenced by the support from the family, especially the husband who is called as Breastfeeding Father. The breastfeeding father is a husband giving full support to his wife in the breastfeeding process. Based on research conducted by (Fitriani Nasustion, 2020) [8], the practice of exclusive breastfeeding increased 2.25 times higher in the group 
of husbands supporting exclusive breastfeeding than in the group of husbands not supporting exclusive breastfeeding. In fact, the husband's involvement in supporting the success of exclusive breastfeeding is still lacking, one of which is because culturally there is a division of roles where the husband acts as the breadwinner and household affairs are entirely the matter of the mother.

Considering the importance of exclusive breastfeeding for the growth and development of children, support from husbands for mothers to provide exclusive breastfeeding is important. Support from the husbands allows the mothers to carry out breastfeeding process easier, so that the mothers' mental condition will be stable and not stressful, and they will not feel exhausted. As a result, the mothers can provide the best breast milk [9], [10]. Based on the results of the analysis, the problem is the lack of a husband's role to be involved in the breastfeeding process, so it is necessary to provide a good solution by introducing and inviting fathers to participate and be involved in the breastfeeding process such as supporting, motivating and accompanying mothers to be successful in giving exclusive breastfeeding [11].

Based on the problems mentioned, the researcher was interested to analyze the influence of the collaborative model between the roles of husbands and health workers on the behavior of exclusive breastfeeding.

\section{Methods}

\section{Type of research}

This was observational research with a Quasi-experimental design [12]. The intervention group consisted of husbands of third-trimester pregnant women, who came from the working area of the Mangkoso Community Health Center and the control group consisted of fathers, who came from the Padongko Community Health Center, each group consisted of 30 people. In the intervention group, a collaborative model was applied, while in the control group, only the $\mathrm{MCH}$ handbook was given. The intervention group held 6 meetings to monitor the application of the collaborative model and the implementation of exclusive breastfeeding. At the end of the research, the knowledge of the husband's role in supporting exclusive breastfeeding and the coverage of exclusive breastfeeding between the intervention group and the control group were measured.

\section{Research place}

This research was performed in the work area of Mangkoso and Padongko Puskesmas, Barru District,
South Sulawesi. This place was selected because of the lowest coverage of exclusive breastfeeding in the working areas of Mangkoso and Padongko in Barru District.

\section{Results}

\section{Knowledge of husband's role}

Bivariate analysis was carried out to determine the influence of the collaboration model on knowledge of the husband's role in supporting exclusive breastfeeding between the intervention group and the control group, which can be seen in Table 1 below.

Table 1: The influence of the collaborative model on knowledge between the intervention group and the control group in Barru District 2021

\begin{tabular}{|c|c|c|c|c|c|c|c|}
\hline \multirow[t]{3}{*}{ Group } & \multicolumn{4}{|c|}{ Knowledge } & \multirow{2}{*}{\multicolumn{2}{|c|}{ Total }} & \multirow[t]{3}{*}{$p$ value } \\
\hline & \multicolumn{2}{|c|}{ Good } & \multicolumn{2}{|c|}{ Poor } & & & \\
\hline & $n$ & $\%$ & $n$ & $\%$ & $n$ & $\%$ & \\
\hline Intervention & 27 & 90.0 & 3 & 10.0 & 30 & 100.0 & 0.000 \\
\hline Control & 8 & 26.7 & 22 & 73.3 & 30 & 100.0 & \\
\hline
\end{tabular}

Table 1 shows that the distribution of respondents who had good knowledge of the husband's role in supporting exclusive breastfeeding behavior was higher in the intervention group, which was 27 people $(90.0 \%)$ than in the control group, which was only 8 people $(26.7 \%)$. The results of statistical tests using the chi-square test obtained $p$ value $=0.000$, which meant that collaborative model provided influence on the increase in the husband's knowledge of the husband's role in supporting exclusive breastfeeding behavior.

\section{Breastfeeding behavior}

The results of the bivariate analysis were carried out to determine the influence of the collaborative model on the behavior of exclusive breastfeeding between the intervention group and the control group, which can be seen in Table 2 below.

Table 2: The influence of the collaborative model on the behavior of exclusive breastfeeding between the intervention group and the control group in Barru District 2021

\begin{tabular}{|c|c|c|c|c|c|c|c|}
\hline \multirow[t]{3}{*}{ Group } & \multicolumn{4}{|c|}{ Exclusive breastfeeding } & \multirow{2}{*}{\multicolumn{2}{|c|}{ Total }} & \multirow[t]{3}{*}{$p$ value } \\
\hline & \multicolumn{2}{|c|}{ Yes } & \multicolumn{2}{|l|}{ No } & & & \\
\hline & $n$ & $\%$ & $\mathrm{n}$ & $\%$ & $\mathrm{n}$ & $\%$ & \\
\hline Intervention & 21 & 70.0 & 9 & 30.0 & 30 & 100.0 & 0.422 \\
\hline Control & 17 & 56.7 & 13 & 43.3 & 30 & 100.0 & \\
\hline
\end{tabular}

Table 2 shows that the distribution of respondents who gave exclusive breastfeeding was higher in the intervention group, which was 21 people $(70.0 \%)$ than the control group, which was only 17 people $(56.7 \%)$. The results of statistical tests using the chi-square test obtained $p$ value $=0.422$ greater than $\alpha=0.05$, so Ho was accepted, which meant that there was no difference in the behavior of exclusive breastfeeding between the intervention group and the 
control group. Statistically, there was no difference because the coverage of exclusive breastfeeding before the intervention given on each group was already different, which was $12.5 \%$ in the intervention group and $35.8 \%$ in the control group. On the other hand, when compared to the increase in coverage of exclusive breastfeeding before and after the intervention, the intervention group experienced an increase of $57.5 \%$ from $12.5 \%$ to $70 \%$. While in the control group the increase was $20.9 \%$ from $35.8 \%$ to $56.7 \%$.

\section{Discussion}

\section{Knowledge}

Knowledge regarding the importance of exclusive breastfeeding not only for wives but also for husbands. This is due to the husband's function as the head of the family, where the knowledge had an influence or be taken into consideration when making decisions, such as the mother's decision to breastfeed, the mother's commitment to breastfeed, and the length of time the mother breastfeeds her baby [13], [14]. This can minimize mistakes in decision-making in exclusive breastfeeding. In addition, with the husband's knowledge of the role in supporting good exclusive breastfeeding, it is expected that the husband shows positive behavior during the process of exclusive breastfeeding [9].

The results showed that the husband's knowledge of the husband's role in exclusive breastfeeding for the intervention group (the work area of the Mangkoso Public Health Center) was quite good, they already understood the role of antenatal care, for example, seeking, providing and discussing all information about pregnancy, preparation of wives for breastfeeding and exclusive breastfeeding. At intranatal time, they already understood their role, for example providing support to reduce anxiety during childbirth, helping to prepare for Early Initiation of Breastfeeding (IMD) such as baby hats and blankets. During postnatal care they already understood their roles, for example, participating in caring for babies such as: helping to change baby's diapers, bathing, doing oxytocin massage to facilitate breast milk, giving milk and taking the baby to sunbathe. However, in the control group (the work area of Puskesmas Padongko) the respondents were still lack of this knowledge, in fact, in general, they did not understand their role as husbands to support exclusive breastfeeding). They did not understand the benefits of breastfeeding, their role during antenatal care, intranatal care, and postnatal care. This ignorance was because husbands were never involved in meetings that discussed the roles of husbands in supporting exclusive breastfeeding. Their involvement was only taking the wife to the integrated health service post or the health center both during pregnancy and during childbirth, but they never participated in meetings, they just stayed outside.

\section{Exclusive breastfeeding behavior}

Collaboration is a concept that describes the facilitation and implementation process that involves multi-organizations to solve problems that could not be easily solved by an organization individually. Collaboration is a mutually beneficial and well-defined relationship that has been agreed by two or more organizations to achieve common goals [15], [16], [17].

If we compared the research results on the increase in coverage of exclusive breastfeeding before and after the intervention, the intervention group experienced an increase of $57.5 \%$ from $12.5 \%$ to $70 \%$. While in the control group the increase was $20.9 \%$ from $35.8 \%$ to $56.7 \%$. This was because there was a clear division of roles between husbands and health workers, in this case midwives, nutrition workers, and cadres in supporting exclusive breastfeeding. In the application of this collaborative model, the husbands were inevitably involved from the time the mothers are pregnant until the babies are 6 months old. The roles of husbands included: providing information on preparation for breastfeeding and exclusive breastfeeding, accompanying and motivating in dealing with childbirth, providing support during Early Initiation of Breastfeeding (IMD), providing support during breastfeeding, and performing oxytocin massage.

The application of the collaborative model in the intervention group was already optimal, but the behavior of exclusive breastfeeding was not optimal. This was due to maternal factors that was insufficient milk production, baby factors in which babies did not want to breastfeed and o type of childbirth factor.

The childbirth by Caesarean Section (SC) provided obstacles to do breastfeeding because mothers who did SC surgery suffered from pain which slightly complicate the breastfeeding process. In addition, anesthesia also caused small-scale production of breast milk, so the mothers finally gave baby formula at the beginning of the birth of the baby. The behavior of giving baby formula at the beginning of birth was inappropriate because actually after the baby is born, they will not starve or in other words, the baby still can survive for $48 \mathrm{~h}$ without any foods/milks. It is because the baby still has food reserves in the baby's body obtained from the placenta while in the mother's womb. Unfortunately, most of the mothers rarely do it [18].

\section{Conclusions and Suggestions}

\section{Conclusion}

1. There was an influence of the collaborative model between the roles of husbands and health workers on the increase in the husband's knowledge of the husband's role in supporting exclusive breastfeeding. 
2. There was an increase in the coverage of exclusive breastfeeding in the intervention group from $12.5 \%$ to $70 \%$.

\section{Suggestions}

1. It is necessary to provide an intervention in the form of education on the importance of nutritious food starting from pre-conception, during pregnancy to the time of breastfeeding.

2. It is necessary to have a government policy to apply the collaborative model between health workers and husbands in order to increase husband's knowledge and behavior of exclusive breastfeeding.

3. It is necessary to perform further research on pre-marital counseling on exclusive breastfeeding.

\section{Acknowledgments}

The author would like to thank the Directorate of Research and Community Service (DRPM) for providing funding to perform this research. Thanks to the Rector and Head of LP2M Universitas Hasanuddin for providing facilities so that this research can be performed. Thanks to the Head of the Barru District Health Office and the Head of the Mangkoso and Padongko Puskesmas for their assistance during the research.

\section{References}

1. Abdullah T, Marwang S, Sudirman J. The collaborative model of husbands and health officers roles in improving mother's behaviour towards providing exclusive breastfeeding: A qualitative study. Syst Rev Pharm. 2020;11(11):350-4.

2. Tewabe T, Mandesh A, Gualu T, Alem G, Mekuria G, Zeleke H. Exclusive breastfeeding practice and associated factors among mothers in Motta town, East Gojjam zone, Amhara Regional State, Ethiopia, 2015 : A cross-sectional study. Int Breastfeed J. 2017;12(12):1-7. https://doi.org/10.1186/s13006-017-0103-3

3. Maharlouei N, Pourhaghighi A, Raeisi H, Zohoori D, Lankarani KB. Factors affecting exclusive breastfeeding, using adaptive LASSO regression. Int J Community Based Nurs Midwifery. 2018;6(3):260-71.

PMid:30035142

4. Nasrabadi M, Vahedian-Shahroodi M, Esmaily $H$, Tehrani $H$,
Md-Phd MG. Factors affecting Exclusive breastfeeding in the first six months of birth : An exploratory-descriptive study. J Midwifwry Reprod Health. 2019;7(3):17471762.

5. Stang $S$, Selin $D$, Suriah $S$, Marwang $S$, Mallongi A, Ishak $H$. The effect of educational media development in increasing knowledge and attitudes on pregnancy complications at sayang rakyat hospital in Makassar. Open Access Maced J Med Sci. 2020;8(2):196-9. https://doi.org/10.3889/oamjms.2020.5227

6. Kementerian Kesehatan Republik Indonesia. Profil Kesehatan Indonesia 2017. Indonesia: Kementerian Kesehatan Republik Indonesia; 2018.

7. Dinas Kesehatan Barru District. Profil Tahunan Dinas Kesehatan Kab. Barru: Dinas Kesehatan Barru District; 2018. https://doi. org/10.31227/osf.io/ptv4r

8. Nasution F. Hubungan dukungan suami dengan pemberian as eksklusif di puskesmas kota rantauprapat kabupaten labuhan batu tahun 2016. J IIm Kebidanan Imelda. 2020;6(1):39-43. https://doi.org/10.36419/jkebin.v5i2.89

9. Ratnasari D, Astria B, Mph P, Scd HH. Family support and exclusive breastfeeding among Yogyakarta mothers in employment. Asia Pacifikc J Clin Nutr. 2017;26(1):31-5. PMid:28625034

10. Windari EN, Dewi AK, Siswanto S. Pengaruh dukungan tenaga kesehatan terhadap pemberian ASI ekslusif di wilayah kerja puskesmas sisir kelurahan sisir Kota Batu. J Issues Midwifery. 2017;1(2):19-24. https://doi.org/10.21776/ ub.joim.2017.001.02.3

11. Ayah AS, Eksklusif AS, Breastfeeding, asupan. J Stud Gend Anak. 2016;3(1):75-91.

12. Sudirman J, Sinrang AW, Marwang S, Nurlaily A, Sabar S, Astuti AT, et al. The analysis estradiol levels against sexual desire in perimenopause women in Makassar, South Sulawesi, Indonesia. Enferm Clin. 2020;30(4):350-3. https://doi. org/10.1016/j.enfcli.2019.07.117 PMid:32204184

13. Sadli M. Hubungan sosial budaya dan peran petugas kesehatan dengan perilaku pemberian MP-ASI dini pada bayi usia $0-6$ Bulan. J Kebidanan. 2019;9(1):15-23. https://doi.org/10.35872/ jurkeb.v11i01.326

14. Mustamin $M$, Amiruddin $R$, Palutturi $S$, Rahman $S A$ Risnah R. Increasing midwifery skill for pregnancy health care with Ammuntuli bija tianang na beja-beja model. Indian J Public Heal Res Dev. 2018;9(9):364-8. https://doi. org/10.5958/0976-5506.2018.01025.2

15. Lestari $\mathrm{Y}$, Saleh A, Syahrir AP. Hubungan interprofesiona kolaborasi dengan pelaksanaan catatan perkembangan terintegrasi di rsud Prof. Dr. H.M. Anwar Makkatutu Kabupaten Bantaeng. J Kesehat. 2017;7(1):85-90.

16. Liunokas OB, Studi P, Waingapu K, Collaboration I, Services TD. Interprofessional collaboration factor analysis in affecting tropical disease services at Kambaniru health center, Waingapu health center, Kanatang health analisis faktor. J Kesehat Prim. 2018;3(1):46-55.

17. Susilaningsih FS. Sosialisasi model praktik kolaborasi interprofesional pelayanan kesehatan rumah sakit. J Apl Ipteks Untuk Masy. 2016;5(1):34-7. https://doi.org/10.31219/osf.io/ bfqup

18. Indrayati N, Nurwijayanti AM, Latifah EM. Perbedaan produks asi pada ibu dengan persalinan normal dan sectio caesarea. Community Publ Nurs. 2018;6(2):95-104. 